\title{
КОММЕНТАРИЙ ЗАКОНОДАТЕЛЬСТВА
}

Астанин B.B.

РЕЦЕНЗИЯ НА КАНДИДАТСКУЮ ДИССЕРТАЦИЮ БАГМЕТА М.А. «ПРОТИВОДЕЙСТВИЕ КОРРУПЦИИ В ПОЛИЦИИ (КРИМИНОЛОГИЧЕСКОЕ ИССЛЕДОВАНИЕ)»

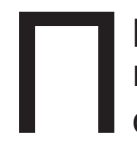
роблема коррупции и борьбы с ее многочисленными проявлениями обладает повышенной актуальностью по многим параметрам: отраслям, последствиям, реагированию, распространенности, и т.п. В контексте подобных перечислений редко выделяются действительно злободневные аспекты антикоррупционной тематики, которые в силу повседневности и ложных представлений о неискоренимости становятся институциональными. Эти замечания справедливо можно отнести к проблемам современного состояния коррупции в полиции и противодействия ее проявлениям. Работ, тем более диссертационных, по этой теме немного (при многочисленности публицистических материалов). В этой связи, заслуживает одобрения избранная научная тема и еe комплексное исследование, предпринятое соискателем ученой степени кандидата юридических наук М.А. Багметом.

При определении актуальности исследования нельзя обойти внимание и институциональные проблемы. Коррупционная пораженность полиции влечет снижение эффрективности реализации государственных задач по обеспечению безопасности личности, общества, государства. Общими итоговыми последствиями распространения коррупции в полиции можно обозначить слабое общество и, как следствие, слабое государство.
Степень обоснованности научных положений, выводов и рекомендаций, содержащихся в диссертации, в значительной степени обусловлена тем, насколько верно обозначены объект и предмет изучения, сформулированы задачи исследования.

Объектом исследования в представленной на отзыв диссертации выступает комплекс общественных отношений, обуславливающих криминологическое противодействие коррупционной преступности в полиции.

Предмет исследования составляют общая и криминологическая характеристики коррупции в полиции, ее причинно-следственные связи, личность коррупционера и потерпевшего от данных преступлений, общие и специальные меры предупреждения коррупции в полиции.

Несмотря на емкость тематики диссертационного исследования достаточными в содержании представляются целевые задачи изыскания, а именно:

- анализ современного российского уголовного законодательства о коррупционных преступлениях;

- определение основных понятий, видов и особенностей коррупционных преступлений, совершаемых полицейскими;

- анализ состояния, динамики, структуры коррупционной преступности в полиции, а также определение ее причин и условий; 


\section{Полицейская деятельность 4 • 2014}

- исследование свойств личности сотрудников полиции-коррупментов;

- разработка общих и специальных мер предупреждения коррупционной преступности в полиции;

- разработка предложений по целенаправленному совершенствованию уголовно-правового законодательства, направленного на противодействие коррупции в полиции.

Научно-практическая значимость диссертации предопределена солидной базой эмпирических данных, подвергнутых автором тщательному изучению. Систематизация и оценка справочно-аналитических документов органов государственной власти, анализ статистики, конкретно-социологический опрос экспертов, мониторинг средств массовой информации, изучение правоприменительных документов - все названные компоненты классического познания криминологически значимых тенденций и закономерностей коррупции в полиции позволили диссертанту сформулировать ряд общих положений, реализация которых на практике борьбы с выделяемым подвидом коррупционной преступности может оцениваться в положительном качестве.

Достоверность положений, выводов и рекомендаций, содержащихся в диссертации, основывается на комплексном использовании положений криминологической науки, уголовного права, социологии. Теоретические положения подкреплены произведенной автором иллюстрацией данных ведомственной статистической отчетности, а также результатами проведенного автором социологического опроса.

Апробацию результатов диссертационного исследования следует признать достаточной, хотя и академической (многочисленные выступления на конференциях и опубликование тематических статей).

Структура диссертации отвечает целям и задачам исследования и состоит из введения, трех глав, включающих в себя во- семь параграфов, заключения, списка литературы и приложений, представленных формами проведенного статистического исследования и интересными программными проектами организационно-правовых документов.

В первой главе диссертации - «Общая характеристика коррупционности в полиции» выдержаны классические позиции теоретических начал исследования криминологически значимых явлений. В частности, в первом параграфе рассматривается понятийный аппарат, разрабатывается операциональное определение коррупции в полиции и уточняются содержательные особенности соответствующих правонарушений, что в конечном счете позволяет выявить специфические ее признаки и проявления в полиции. Второй параграф закономерно для избранной специальности диссертационной работы представлен уголовно-правовой характеристикой коррупционных преступлений, совершаемых полицейскими. Отрадно обстоятельство не просто внимания диссертанта к проблемам квалификации коррупционных преступлений через призму УК РФ и доктрину уголовного права, но и включение в научный оборот положений новых юридически значимых документов, в частности Постановления Пленума Верховного Суда Российской Федерации от 0.07.2013 № 24 «О судебной практике по делам о взяточничестве и об иных коррупционных преступлениях», которое подвергнуто обширному анализу. Между тем, подробное, а местами, как может показаться, излишнее внимание автора к указанному документу произведено предметно-тематически и в контексте проблем, поднимаемых в диссертации, причем в тесной корреляции с иными правоприменительными документами.

Вторая глава диссертации - «Криминологическая характеристика коррупционной преступности в полиции» с первого ее параграфра, в котором освещается динамика состояния коррупционной преступно- 
сти в полиции, отражает глубокую линию полиотраслевых проблем репрезентативных показателей закономерностей коррупционной преступности, рассмотрение которых убеждает в том, что объективные их начала заложены в традиционных, сложившихся в криминологической науке методах познания преступности. В данной части работы неординарным представляется подход автора, выраженный в том, что аналитическая ее часть (по существу статистический анализ данных уголовной статистики) завершается предложением законодательного характера - проектируемой новеллой в виде статьи 292.2 УК РФ - «Укрытие преступлений».

Второй параграф второй главы посвящен рассмотрению причинного комплекса коррупционной преступности, которому дана подробная и развернутая система классификации на основе фриксируемых в специальной юридической литературе фракторах (социокультурные, политические, социально-экономические, правовые, психологические, управленческие), обусловливающих современные коррупционные проявления. Заслуживает внимания произведенная автором корреляция причинных факторов с тематикой исследования, что выразилось в их актуализации для сотрудников полиции, относящихся к разным группам должностей.

Параграф третьей второй главы диссертации отличается не только оригинальным названием в которое вынесено предложенное автором и вынесенное на защиту определение «коррупмента», но и полиотраслевым своим содержанием. Свойства личности коррумпированного или подверженного коррупционным рискам сотрудника полиции рассматриваются в контексте криминологически значимых показателей, а также психологических и социально-демографических.

Третья глава «Общие и специальные меры предупреждения коррупционной преступности в полиции» имеет неор- динарное для криминологических научных работ начало, выраженное в первостепенном освещении международного опыта борьбы с коррупционной преступностью в полиции. Преимущественно обширное рассмотрение получил анализ опыта США и Индонезии, фрагментарное - Канады и Великобритании, Германии и Франции, а также Испании, Японии и Израиля. Невольно обращает на себя внимание выделение диссертантом прерогативы специфических мер профилактики и предупреждения коррупции в полиции, принятых в указанных странах.

Во втором параграфе рецензируемой главы, который назван «Уголовно-правовое противодействие преступлениям коррупционной направленности, совершенным полицейскими, и иные общесоциальные меры», де-фракто представлена конкретно-тематическим анализом антикоррупционных законодательных норм против коррупции в полиции в контексте общих мер предупреждения. Наибольший интерес представляют суждения об идеологических компонентах антикоррупционных мероприятий, рекомендуемых автором к реализации. Весьма актуально звучат предложения о коррекции правового сознания сотрудников полиции, правовое их обучение и воспитание, а также ряд мер пропагандистского антикоррупционного содержания.

В заключительном параграфе диссертации приведен анализ возможностей реализации специальных мер предупреждения коррупционной преступности в полиции, которые классифицированы по сорерам применения. В частности, оригинальное звучание имеют суждения по специальным превентивным мерам в идеологической, кадровой и виктимологической сорерах. Удачным является предварительно проведенное в указанном разделе работы опосредованное обоснование автором программных антикоррупционных профилактических документов, которые вошли в Приложения к диссертации. 


\section{Полицейская деятельность 4 • 2014}

Достаточным является заключение диссертации, где содержатся значимые предложения, которые актуализируют многие положения работы, выносимых на защиту.

Содержательная часть подготовленной и представленной М.А. Багметом к защите диссертации позволяет утверждать, что она является научно-квалификационной работой, в которой на основе проведенного исследования содержится решение задач, имеющих значение для оптимизации противодействия коррупции в полиции. Выводы и предложения диссертанта могут быть использованы в правоприменительной практике и законотворческой деятельности при необходимом совершенствовании предупреждения коррупционных проявлений в многочисленных областях деятельности, связанной с обеспечением правоохранительной деятельности и национальной безопасности ${ }^{1}$.

Наряду с отмеченными положительными сторонами диссертационного исследования оно не лишено положений, требующих разъяснения, а также отдельных недостатков.

1. Отмечаемые автором криминологически значимые признаки коррупционной преступности в полиции консолидированы в очевидных характеристиках (положение первое и второе, выносимое на защиту), которые могут быть аналогично представлены в отношении коррупционной преступности в других правоохранительных органах. С учетом этого обстоятельства, диссертанту предлагается уточнить и выделить особенное из общего.

2. Оговорка диссертанта о недопущении искусственного расширения перечня коррупционных преступлений полицейских совершенна справедлива. Однако предложенные рамки выделяемого

\footnotetext{
${ }^{1}$ Куракин А.В. Предмет административно-правового регулирования противодействия коррупции в полиции. Домодедово, 2013.
}

подвида преступности в семи составах преступлений, предусмотренных УК РФ (ст.ст. 285, 286, 290, 291, 291.1, 292 и 303), не находят убедительной аргументации. Почему нельзя оценивать в качестве коррупционного преступления полицейских, совершенное ими деяние, предусмотренное ст. 304 УК РФ? Почему не включены в исследуемую криминологически значимую совокупность рассматриваемого вида преступности предикатные уголовнонаказуемые деяния? Ведь именно они дают полную картину коррупционных преступных технологий в сфере полицейской деятельности, прежде всего процессуальной (учитывая события, связанные с проблемами законности в работе ГУЭБиК МВД России).

3. Уделяя подробное внимание де-факто зарубежной (но не международной как определено в названии §1 глава 3) практике противодействия коррупции, автор между тем не сопроводил добротный анализ опыта, оценками и предложениями его имплементации в российских условиях.

4. Как представляется, ошибочно, в положении пятом, выносимом на защиту, автор отнес к условиям коррупционной преступности, связанных с личностью полицейских «стойкое отсутствие (A.B.) желания получать за свою работу незаконное вознаграждение в виде взяток и любых иных форм и видов подношений и услуг». При редакционном изменении данного тезиса, а именно при исключении слов «стойкое отсутствие», положение пятое будет звучать безупречно.

5. Значительная часть второго параграфа третьей главы, имеющего название «Уголовно-правовое противодействие преступлениям коррупционной направленности, совершенным полицейскими, и иные общесоциальные антикоррупционные меры», представлена пре- 
Комментарий законодательства

имущественно обзором нормативных правовых актов по профилактике коррупции, которые представляют значение для темы исследования в рамках криминологической теории предупреждения. Между тем в названной части диссертации не нашли отражение собственно уголовно-правовые аспекты противодействия. Означает ли это, что здесь автор пытался выразить и определить профрилактику коррупционной преступности полицейских в ее уголовно-правовом назначении, или на этот счет имеются другие соображения?

Приведенные замечания не влияют на общую положительную оценку представленного диссертационного исследования, которое по своей актуальности, новизне постановки и решению исследуемых проблем, теоретическому уровню, определенной практической полезности, обоснованности и достоверности научных результатов, соответствует требованиям, предъявляемым к кандидатским диссертациям Положением о порядке присуждения ученых степеней.

\section{Библиография:}

1. Астанин В.В. Противодействие коррупции и предупреждение коррупционных рисков в деятельности государственных служащих. М.: Европейский учебный институт МГИМО (У) МИД РФ. 2011. С. 276.

2. Куракин А.В., Костенников М.В. Административно-правовое противодействие коррупции в системе государственной службы и в деятельности сотрудников полиции Российской Федерации и зарубежных государств // NB: Российское полицейское право. - 2013. - 1. - C. 65-83.

3. Куракин А.В. Компетенция полиции в сфере реализации законодательства об административных правонарушениях // NB: Административное право и практика администрирования. - 2013. - 4. - С. $28-48$.

4. Криминология / Под общей ред. А.И. Долговой. - М.: Инфра-М, 1997.

5. Костенников М.В. К вопросу о противодействии коррупции в полиции // NB: Административное право и практика администрирования. - 2013. - 12. - C. 66 - 73. DOI: 10.7256/23069945.2013.12.10700. URL: http://www.e-notabene.ru/al/article_10700.html

6. М.В. Костенников К вопросу о противодействии коррупции в полиции // Административное и муниципальное право. - 2013. - 1. - С. 49 - 50. DOI: 10.7256/1999-2807.2013.01.9.

7. Костенников М.В., Куракин А.В. Административно-правовое противодействие коррупции в системе государственной службы и в деятельности сотрудников полиции Российской Федерации и зарубежных государств. // Полицейская деятельность. - 2011. - 1. - С. 10 - 16.

8. Куракин А.В., Костенников М.В. Административно-правовое противодействие коррупции в системе государственной службы и в деятельности сотрудников полиции Российской Федерации и зарубежных государств // NB: Российское полицейское право. - 2013. - 1. - С. 65 - 83. DOI: 10.7256/2306-4218.2013.1.735. URL: http://www.e-notabene.ru/pm/article_735.html

9. М.В. Костенников, А.В. Куракин, И.Н. Кошелев Административно-правовое регулирование обеспечения собственной безопасности и противодействия коррупции в органах внутренних дел (ч. 2). // Административное и муниципальное право. - 2011. - 2. - С. 38 - 45.

10. Куракин А.В. Административно-правовые аспекты юридической ответственности в механизме противодействия коррупции в системе государственной службы Российской Федерации // NB: Административное право и практика администрирования. - 2013. - 7. - С. 137 - 157. DOI: 10.7256/2306-9945.2013.7.9954. URL: http://www.e-notabene.ru/al/article_9954.html 


\section{Полицейская деятельность 4 • 2014}

11. Куракин А.В. Компетенция полиции в сфере реализации законодательства об административных правонарушениях // NB: Административное право и практика администрирования. - 2013. - 4. - C. 28 - 48. DOI: 10.7256/2306-9945.2013.4.8841. URL: http://www.e-notabene. ru/al/article_8841.html

\section{References (transliteration):}

1. Astanin V.V. Protivodeistvie korruptsii i preduprezhdenie korruptsionnykh riskov v deyatel'nosti gosudarstvennykh sluzhashchikh. M.: Evropeiskii uchebnyi institut MGIMO (U) MID RF. 2011. S. 276.

2. Kurakin A.V., Kostennikov M.V. Administrativno-pravovoe protivodeistvie korruptsii v sisteme gosudarstvennoi sluzhby i v deyatel'nosti sotrudnikov politsii Rossiiskoi Federatsii i zarubezhnykh gosudarstv // NB: Rossiiskoe politseiskoe pravo. - 2013. - 1. - C. 65-83.

3. Kurakin A.V. Kompetentsiya politsii v sfere realizatsii zakonodatel'stva ob administrativnykh pravonarusheniyakh // NB: Administrativnoe pravo i praktika administrirovaniya. - 2013. -4 . - C. $28-48$.

4. Kostennikov M.V. K voprosu o protivodeistvii korruptsii v politsii // NB: Administrativnoe pravo i praktika administrirovaniya. - 2013. - 12. - C. 66 - 73. DOI: 10.7256/2306-9945.2013.12.10700. URL: http://www.e-notabene.ru/al/article_10700.html

5. M.V. Kostennikov K voprosu o protivodeistvii korruptsii v politsii //Administrativnoe i munitsipal'noe pravo. - 2013. - 1. - C. 49 - 50. DOI: 10.7256/1999-2807.2013.01.9.

6. Kostennikov M.V., Kurakin A.V. Administrativno-pravovoe protivodeistvie korruptsii v sisteme gosudarstvennoi sluzhby i v deyatel'nosti sotrudnikov politsii Rossiiskoi Federatsii i zarubezhnykh gosudarstv. // Politseiskaya deyatel'nost'. - 2011. - 1. - C. $10-16$.

7. Kurakin A.V., Kostennikov M.V. Administrativno-pravovoe protivodeistvie korruptsii v sisteme gosudarstvennoi sluzhby i v deyatel'nosti sotrudnikov politsii Rossiiskoi Federatsii i zarubezhnykh gosudarstv // NB: Rossiiskoe politseiskoe pravo. - 2013. - 1. - C. 65 - 83. DOI: 10.7256/23064218.2013.1.735. URL: http://www.e-notabene.ru/pm/article_735.html

8. M.V. Kostennikov, A.V. Kurakin, I.N. Koshelev Administrativno-pravovoe regulirovanie obespecheniya sobstvennoi bezopasnosti i protivodeistviya korruptsii v organakh vnutrennikh del (ch. 2). // Administrativnoe i munitsipal'noe pravo. - 2011. - 2. - C. $38-45$.

9. Kurakin A.V. Administrativno-pravovye aspekty yuridicheskoi otvetstvennosti v mekhanizme protivodeistviya korruptsii v sisteme gosudarstvennoi sluzhby Rossiiskoi Federatsii // NB: Administrativnoe pravo i praktika administrirovaniya. - 2013. - 7. - C. 137 - 157. DOI: 10.7256/23069945.2013.7.9954. URL: http://www.e-notabene.ru/al/article_9954.html

10. Kurakin A.V. Kompetentsiya politsii $v$ sfere realizatsii zakonodatel'stva ob administrativnykh pravonarusheniyakh // NB: Administrativnoe pravo i praktika administrirovaniya. - 2013. - 4. - C. 28 - 48. DOI: 10.7256/2306-9945.2013.4.8841. URL: http://www.e-notabene.ru/al/article_8841.html 